\title{
Dietary amino acids : effect of depletion and recovery on protein synthesis in vitro in rat skeletal muscle and liver
}

\author{
By P. T. OMSTEDT AND ALEXANDRA vON DER DECKEN \\ The Wenner-Gren Institute for Experimental Biology, \\ Stockholm, Sweden
}

(Received 16 April 1973 - Accepted I2 July 1973)

\begin{abstract}
I. Rats were given diets containing $200 \mathrm{~g} / \mathrm{kg}$ of a complete or incomplete amino acid mixture or of high- or low-quality proteins. After $6 \mathrm{~d}$ the amino acid-incorporating activity of ribosomes from skeletal muscle and liver was studied.

2. The level of isotope incorporation relative to ribosomal RNA was similar for casein supplemented with methionine and for a complete amino acid mixture with the composition of whole-egg protein. Per wet weight of tissue there was a significant decrease after feeding with the complete arnino acid mixture.

3. There was a significant decrease in activity after feeding with amino acid mixtures deficient in lysine, methionine or tryptophan. In skeletal muscle, but not in liver, the ribosomal activity was less than that obtained with wheat gluten. Activity per wet weight of both tissues was less than that obtained with wheat gluten.

4. Refeeding with methionine for $\mathrm{I} d$ resulted in complete restoration of ribosomal activity and activity per wet weight in skeletal muscle.

5. After lysine deficiency, protein synthesis per unit wet weight of both tissues and ribosomal activity in liver were not restored after $2 \mathrm{~d}$ of refeeding. Recovery of ribosomal activity in skeletal muscle was complete after $\mathbf{I}$ d.

6. Rats receiving the $200 \mathrm{~g}$ casein/ $\mathrm{kg}$ diet supplemented with methionine at daily energy levels of $263,176,14 \mathrm{I}$ and $106 \mathrm{KJ}(62 \cdot 6,42 \cdot 1,33.7$ and $25 \cdot 3 \mathrm{kcal})$ showed no changes in ribosomal activity, but there was a significant decrease in activity per wet weight when I06 KJ were given.
\end{abstract}

The extent to which dietary proteins are utilized for body metabolism depends on their amino acid composition. Skeletal muscle is one of the tissues that is affected by alterations in the diet. There is a significant reduction in the protein turnover after giving rats a low-protein diet (Waterlow \& Stephen, I968). The ability of ribosomes to incorporate amino acids into protein in vitro is correlated with the biological value of the nitrogen sources (von der Decken \& Omstedt, I970, I972; Omstedt \& von der Decken, I972; Omstedt, von der Decken, Hedenskog \& Mogren, I973). In the present investigation dietary proteins were replaced by defined amino acid mixtures, which have the advantage that changes in their composition are easily made to suit the purpose of the investigation.

The present study deals with some aspects of the effects of various dietary proteins and amino acid mixtures on the protein synthetic ability of ribosomes from skeletal muscle and liver of rats. The metabolic utilization of a high-quality protein was compared with that of an amino acid mixture which had a composition that gave optimal utilization; alternatively, a low-quality protein and a mixture deficient in a single amino acid were compared. In addition, the extent of recovery from deficiency of a single amino acid was studied. Since food intake may vary, the effect on protein synthesis of various dietary levels of energy was investigated. In this instance, the diet contained $200 \mathrm{~g}$ of a high-quality protein $/ \mathrm{kg}$. 
Table $\mathrm{I}$. Composition of the complete mixture of dietary amino acids (according to whole-egg pattern taken from FAO, r970)

$\begin{array}{lclc}\text { L-Amino acid } & \begin{array}{c}\text { Amount } \\ \text { (mg/g nitrogen) }\end{array} & \text { L-Amino acid } & \begin{array}{c}\text { Amount } \\ \text { (mg/g nitrogen) }\end{array} \\ \text { Alanine } & 370 & \text { Leucine } & \mathbf{5 5} \\ \text { Arginine } & 38 \mathrm{I} & \text { Lysine } & 436 \\ \text { Aspartic acid } & 60 \mathrm{I} & \text { Methionine } & \mathbf{2} \text { 工0 } \\ \text { Asparagine } & 38 \mathrm{I} & \text { Phenylalanine } & \mathbf{3 5} \\ \text { Cystine } & \mathrm{I} 5 & \text { Proline } & 260 \\ \text { Glutamic acid } & 796 & \text { Serine } & 478 \\ \text { Glutamine } & 600 & \text { Threonine } & 320 \\ \text { Glycine } & 207 & \text { Tryptophan } & 93 \\ \text { Histidine } & \mathrm{I52} & \text { Tyrosine } & 260 \\ \text { Isoleucine } & 393 & \text { Valine } & 428\end{array}$

EXPERIMENT A L

Materials. Chemicals were of AR grade whenever possible; the sources were given in detail previously (von der Decken, I968, I969). In addition, L-[U-14C]phenylalanine (specific radioactivity $100 \mathrm{mCi} / \mathrm{mmol}$ ), DL-3- $\left[\mathrm{I}-{ }^{14} \mathrm{C}\right]$ phenylalanine (specific radioactivity $20 \mathrm{mCi} / \mathrm{mmol}$ ), and ${ }^{14} \mathrm{C}$-labelled algal protein hydrolysate (specific radioactivity $45 \mathrm{Ci}$ /atom of carbon), were obtained from the Radiochemical Centre, Amersham, Bucks.; $\alpha$-amylase from Worthington Biochemical Corp., Freeshold, NJ, USA; L-amino acids from Tanabe Seiyaka Co. Ltd, Osaka, Japan, Fluka AG, Büchs, SG, Switzerland, and E. Merck AG, Darmstadt, Germany.

Animals and dietary treatments. Sprague-Dawley rats about $35 \mathrm{~d}$ of age and weighing $100-130 \mathrm{~g}$ were kept in individual cages in a room with $\mathrm{I} 2 \mathrm{~h}$ of light (between 07.00 hours and 19.00 hours), 55-60\% humidity and a temperature of $22^{\circ} \pm 1$. Food and water were given ad lib.

After a prefeeding period of $3 \mathrm{~d}$ on a diet containing $100 \mathrm{~g}$ protein $/ \mathrm{kg}$ (von der Decken \& Omstedt, I972) the rats received the experimental diets containing $200 \mathrm{~g}$ protein or amino acid mixture per $\mathrm{kg}$. The composition of the complete amino acid mixture is shown in Table $\mathbf{r}$. When one amino acid was excluded, the corresponding amount of nitrogen was added in the form of glycine. Other components of the diet were as described earlier (von der Decken \& Omstedt, 1972). Food was given every day at 16.00 hours. The rats were decapitated at 08.00 hours without previous fasting. Comparison of the diets is made within but not between the various test series (Omstedt \& von der Decken, r972). Therefore, each series includes a nitrogen source of high biological value as a reference.

Expt I. Groups of four rats received diets containing casein (supplemented with $3 \mathrm{~g}$ methionine $/ \mathrm{kg}$ ), wheat gluten, a complete amino acid mixture or mixtures deficient in lysine, methionine or tryptophan as nitrogen sources (see Tables 2-4) for 6 consecutive days. The amount of food provided was $263 \mathrm{KJ}(62 \cdot 6 \mathrm{kcal}) / \mathrm{d}$.

Expt 2. To examine the extent of recovery from partial amino acid deficiency groups of four rats received the complete amino acid mixture or a mixture deficient in lysine or methionine for 6 consecutive days. In addition, groups of four rats received the 
amino-acid deficient mixture for $6 \mathrm{~d}$ and a complete mixture for $\mathrm{x}$ or 2 additional $\mathrm{d}$. The amount of energy provided was $263 \mathrm{KJ} / \mathrm{d}$.

Expt 3. In order to investigate whether a reduced food intake might be responsible for a decreased capacity for protein synthesis, groups of four rats were given a diet containing, per $\mathrm{kg}, 200 \mathrm{~g}$ casein supplemented with $3 \mathrm{~g}$ methionine $/ \mathrm{kg}$ at an energy level of either $263,176,14 \mathrm{I}$ or $103 \mathrm{KJ}$ per $\mathrm{d}(62 \cdot 6,42 \cdot 1,33 \cdot 7$ or $25 \cdot 3 \mathrm{kcal})$ for 6 consecutive days.

Preparation of ribosomes from skeletal muscle. The ribosomes were prepared from $3 \mathrm{~g}$ of skeletal muscle as described by Peters, Richardson, Small \& White (1970) with slight modifications (Omstedt \& von der Decken, 1972).

Preparation of ribosomes from liver. Polyribosomes were prepared by the method of Wettstein, Staehelin \& Noll (1963).

Amino acid incorporation in vitro. The total volume used was $150 \mu$ l. The incubation mixture contained: phosphoenolpyruvate Io mM, ATP I mM, GTP $0.1 \mathrm{mM}$, pyruvate kinase $(E C 2.7 .1 .40) 40 \mu \mathrm{g} / \mathrm{ml}$, amino acid mixture $12.5 \mu \mathrm{g} / \mathrm{ml}$ (von der Decken, I 968 ) lacking the radioactive one, $\left[{ }^{14} \mathrm{C}\right]$ amino acid (as indicated in the tables) $0.05 \mu \mathrm{Ci}$ of the $\mathrm{L}$-form, or $0.017 \mu \mathrm{Ci}$ of the algal hydrolysate, $\mathrm{MgCl}_{2} 7 \mathrm{mM}, \mathrm{KCl} 0.08 \mathrm{M}$, Tris- $\mathrm{HCl}$ buffer $\left(\mathrm{pH} 7.8\right.$, measured at $\left.25^{\circ}\right) 0.035 \mathrm{M}$, sucrose $0.25 \mathrm{M}$, Sephadex-treated liver cell sap (von der Decken, 1968 ) corresponding to $0.5 \mathrm{mg}$ of protein, and increasing amounts of ribosomes in the range of 8-25 $\mu \mathrm{g}$ RNA (Omstedt \& von der Decken, 1972). When ${ }^{14} \mathrm{C}$-labelled protein hydrolysate was used no amino acid mixture was added. After incubation for 12 min at $35^{\circ}$, roo $\mu 1$ were transferred to filter-paper discs, extracted (Mans \& Novelli, I961) and counted for radioactivity at $40 \%$ efficiency (von der Decken, 1968). The capacity for protein synthesis was expressed as activity per mg ribosomal RNA or $g$ wet weight of tissue. Differences in activity were considered statistically significant when the $P$ value was 0.05 or less.

Analytical methods. Protein was determined by the method of Lowry, Rosebrough, Farr \& Randall (195I) with bovine serum albumin as a standard. RNA was extracted in $0.4 \mathrm{M}-\mathrm{HClO}_{4}$, and the extinction at $260 \mathrm{~nm}$ was measured (Ogur \& Rosen, 1950); $\alpha$-amylase was added to the ribosomes (Peters et al. 1970) before extraction with $\mathrm{HClO}_{4}$.

\section{RESULTS}

\section{Expt I. Effect of feeding with a complete or an incomplete amino acid mixture}

Casein and a complete amino acid mixture were similarly active, per mg ribosomal RNA, in incorporating amino acids into protein in both skeletal muscle and liver; but significant differences were obtained per $\mathrm{g}$ wet weight of the tissues (Tables $z$ and 3). In agreement with earlier observations, the capacity for protein synthesis significantly decreased when wheat gluten was given as a protein source instead of casein. In skeletal muscle a further decrease was observed when the rats were given a lysine-deficient amino acid mixture (Table 2 ). In liver the activity per $\mathrm{mg}$ ribosomal RNA with a lysine-deficient mixture was that obtained with wheat gluten, but there was a significant decrease per $g$ wet weight of liver. A reduction in protein 
Table 2. Expt r. Effect of lysine-deficient and other diets given for 6 d on the incorporation of $\left[{ }^{14} \mathrm{C}\right]$ phenylalanine into protein by ribosomes from skeletal muscle and liver of rats

(Mcan values with their standard errors for four rats/group)

Skeletal muscle

Phenylalanine
incorpotated (pmol)

Per mg
ribosomal
RNA $\quad$ Por wet wt

Dietary N source

Casein

Complete amino acid mixture

Wheat gluten

Lys-deficient amino acid mixture

Level of significance, $P$;

Casein $v$. complete

Casein v. wheat gluten

Casein v. lys-deficient

Complete $v$. wheat gluten

Complete $v$. lys-deficient

Wheat gluten $v$. lys-deficient
$279 \cdot 3 \pm 13 \cdot 3 \quad 55 \cdot 6 \pm 1 \cdot 5$

$282 \cdot 7 \pm$ II. $\quad 50 \cdot 3 \pm 0.9$

$24 I \cdot 8 \pm$ II $8 \quad 36 \cdot I \pm 2 \cdot 3$

I $50.5 \pm 7.8 \quad 233 \pm$ I. I

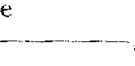

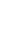

mg
ribosornal
RNA/

g wet wt

$0.20 \pm 0.01$

$0.18 \pm 0.01$

$0.15 \pm 0.01$

$0.15 \pm 0.01$
Liver

Phenylalanine incorporated (pmol)

Per mg
ribosoma!
RNA

mg ribosomal RNA/

$636 \cdot 2 \pm 19 \cdot 1 \quad 767 \cdot 9 \pm 23 \cdot 1 \quad$ I.21 \pm 0.09

$657 \cdot 0 \pm 243 \quad 632 \cdot 8 \pm 23 \cdot 5 \quad 0.97 \pm 0.06$

$58 \mathrm{I} \cdot \mathrm{I} \pm \mathrm{I} 7 \cdot 9 \quad 604 \cdot 8 \pm \mathrm{I} 8.6 \quad \mathrm{I} \cdot 05 \pm 0.05$

$574.6 \pm 23.2 \quad 530.9 \pm 23.5 \quad 0.02 \pm 0.06$

Six and four determinations were made per rat with skeletal muscle and liver, respectively.

NS, not significant.

Table 3. Expt I. Effect of methionine-deficient and other diets given for $6 d$ on the incorporation of $\left[{ }^{14} \mathrm{C}\right]$ phenylalanine into protein by ribosomes from skeletal muscle and liver of rats

$\begin{array}{rlclcc}\text { NS } & <0.01 & \text { NS } & \text { NS } & <0.001 & <0.1 \\ <0.05 & <0.02 & <0.02 & <0.05 & <0.001 & \text { NS } \\ <0.001 & <0.001 & <0.05 & <0.05 & <0.001 & <0.05 \\ <0.02 & <0.001 & <0.01 & <0.02 & N S & \text { NS } \\ <0.001 & <0.001 & <0.05 & <0.05 & <0.01 & \text { NS } \\ <0.001 & <0.001 & N S & N S & <0.02 & \text { NS }\end{array}$

(Mean values with their standard crrors for four rats/group)

Skeletal muscle

Phenylalanine incorporated (pmol)

$\overbrace{\begin{array}{c}\text { Per mg } \\ \text { ribosomal } \\ \text { RNA }\end{array} \text { g wer wt }}$

Dietary $N$ source

Casein

Complete amino acid mixture

Wheat gluten

Met-deficient amino acid mixture

Level of significance, $P$ :

Casein v. complete

Casein $v$. wheat gluten

Casein $v$. met-deficient

Complete v. wheat gluten

Complete $v$. met-deficient

Wheat gluten $v$ met-deficient $<0.00$

$$
\begin{aligned}
& \mathrm{NS}<0.01 \\
& <0.02 \\
& <0.001 \\
& <0.00 \text { I } \\
& <0.001 \\
& <0.001
\end{aligned}
$$$$
<O \cdot I
$$$$
<0.001
$$$$
<0.001
$$$$
<0.02
$$

Liver

Phenylalanine incorporated (pmol)

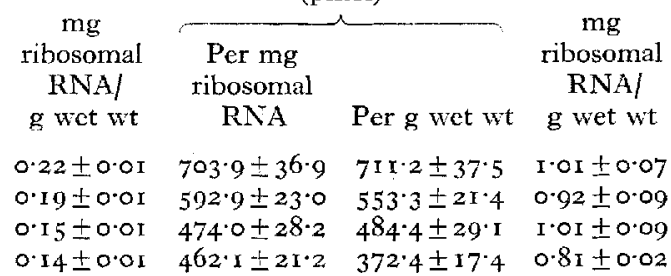

$\begin{array}{lll}<0.02 & <0.001 & \text { NS } \\ <0.001 & <0.001 & \text { NS } \\ <0.001 & <0.001 & <0.05 \\ <0.01 & <0.1 & \text { NS } \\ <0.001 & <0.001 & \text { NS } \\ \text { NS } & <0.001 & <0.1\end{array}$

For further details see Table 2. NS, not significant. 
Table 4. Expt $\mathbf{1}$. Comparison between effects of dietary amino acid mixtures deficient in lysine, methionine or tryptophan on the incorporation of $\left[{ }^{14} \mathrm{C}\right]$ phenylalanine into protein by ribosomes from skeletal muscle and liver of rats after $6 d$ of dietary treatment

(Mean values with their standard errors for four rats/group)

\begin{tabular}{|c|c|c|c|c|c|c|}
\hline & & eletal musc & & & Liver & \\
\hline & $\begin{array}{r}\text { Phenyla } \\
\text { incorporate }\end{array}$ & $\begin{array}{l}\text { anine } \\
d(p m o l)\end{array}$ & & $\begin{array}{r}\text { Phenylalanin } \\
(\mathrm{p}\end{array}$ & $\begin{array}{l}\text { incorporated } \\
\text { nol) }\end{array}$ & \\
\hline $\begin{array}{l}\text { Dietary amino acid } \\
\text { mixture }\end{array}$ & $\begin{array}{l}\text { Per mg } \\
\text { ribosomal } \\
\text { RNA }\end{array}$ & $\begin{array}{c}\text { Per } \\
\text { g wet wt }\end{array}$ & $\begin{array}{l}\text { ribosomal } \\
\text { RNA/ } \\
\text { g wet wt }\end{array}$ & $\begin{array}{c}\text { Per mg } \\
\text { ribosomal } \\
\text { RNA }\end{array}$ & Per g wet wt & $\begin{array}{l}\text { ribosomal } \\
\text { RNA/ } \\
\text { g wet wt }\end{array}$ \\
\hline Complete & $290 \cdot 9 \pm 12 \cdot 5$ & $59 \cdot 4 \pm 2 \cdot 8$ & $0.20 \pm 0.01$ & $687 \cdot 4 \pm 44 \cdot 3$ & $789 \cdot 5 \pm 5 I \cdot 2$ & $1 \cdot 14 \pm 0.09$ \\
\hline Lys-deficient & $214 \cdot 5 \pm 12 \cdot 2$ & $3 x \cdot 6 \pm 2 \cdot 2$ & $0.14 \pm 0.01$ & $521 \cdot 5 \pm 23 \cdot 7$ & $523.6 \pm 23.8$ & $1.00 \pm 0.06$ \\
\hline Met-deficient & $183.0 \pm 9.9$ & $25 \cdot 0 \pm 1 \cdot 9$ & $0.14 \pm 0.02$ & $570 \cdot 1 \pm \mathrm{II} \cdot 8$ & $537 \cdot 6 \pm$ I $1 \cdot 1$ & $0.94 \pm 0.09$ \\
\hline Try-deficient & $162 \cdot 8 \pm 4 \cdot 0$ & $23 \cdot 0 \pm 0.8$ & $0.14 \pm 0.01$ & $534.1 \pm 18 \cdot 1$ & $509 \cdot 6 \pm 17 \cdot 2$ & $0.96 \pm 0.06$ \\
\hline Level of significance, $P$ : & & & & & & \\
\hline Complete $v$. Iys-deficient & $<0.001$ & $<0.001$ & $<0.05$ & $<0.01$ & $<0.001$ & NS \\
\hline Complete $v$. met-deficient & $<0.001$ & $<0.00 I$ & $<0.02$ & $<0.02$ & $<0.001$ & NS \\
\hline Complete $v$. try-deficient & $<0.001$ & $<0.001$ & $<0.01$ & $<0.0 \mathrm{r}$ & $<0.001$ & NS \\
\hline Lys-deficient $v$. met-deficient & $t<0.05$ & $<0.05$ & NS & $<0 \cdot 1$ & NS & NS \\
\hline Lys-deficient $v$. try-deficient & $<0.001$ & $<0.001$ & NS & $\mathrm{NS}$ & NS & NS \\
\hline Met-deficient $v$. try-deficient & $t \quad \mathrm{NS}$ & NS & NS & NS & NS & NS \\
\hline
\end{tabular}

For further details see Table 2 . NS, not significant.

synthesis was observed also when a methionine-deficient amino acid mixture was given to the rats. As compared with wheat gluten, there was a pronounced decrease in activity in skeletal muscle; in liver the decrease was apparent only per $\mathrm{g}$ wet weight of tissue and not per mg ribosomal RNA (Table 3).

When groups of rats given diets deficient in lysine, methionine or tryptophan were compared with rats that had received the complete amino acid mixture, statistically significant differences were observed; with the complete amino acid mixture the amino acid-incorporating activity was greater, both in skeletal muscle and in liver (Table 4 ).

Differences in the effect on protein synthesis were observed, especially in skeletal muscle, between the amino acid-deficient diets. The most pronounced effect was obtained with tryptophan deficiency, followed by methionine and finally lysine deficiency. The differences between methionine and tryptophan deficiency did not reach a significant level. In liver, lysine deficiency and tryptophan deficiency had a similar effect on protein synthesis; with methionine deficiency the decrease in activity was less pronounced.

The amount of ribosomal RNA per $g$ wet weight of skeletal muscle suggested a diet-dependent change in the ribosomal content (Tables 2-4). The effect was less pronounced in liver where, as compared with casein supplemented with methionine, complete lysine or methionine deficiency showed a significant decrease; with wheat gluten the amount of RNA was that of the high-quality protein. 
Table 5. Expt 2. Effect on protein synthesis in skeletal muscle of rats of refeeding with methionine after $6 d$ on a methionine-deficient diet

(Mean values with their standard errors for four rats/group)

\begin{tabular}{|c|c|c|c|}
\hline & \multicolumn{2}{|c|}{ Phenylalanine incorporated (pmol) } & mg ribosomai RNA \\
\hline Dietary amino acid mixture & $\begin{array}{l}\text { Per mg ribosomal } \\
\text { RNA }\end{array}$ & Per g wet wt & Perg wet wt \\
\hline Complete for $6 \mathrm{~d}$ & $256 \cdot 1 \pm 6 \cdot 2$ & $46 \cdot 4 \pm 2 \cdot 3$ & $0.18 \pm 0.01$ \\
\hline $\begin{array}{l}\text { Met-deficient for } 6 \mathrm{~d} \text {, thereafter } \\
\text { complete for } 2 \mathrm{~d}\end{array}$ & $2649 \pm 17.5$ & $43 \cdot 9 \pm 2 \cdot 0$ & $0.16 \pm 0.01$ \\
\hline $\begin{array}{l}\text { Met-deficient for } 6 \mathrm{~d} \text {, thereafter } \\
\text { complete for } \mathrm{I} \mathrm{d}\end{array}$ & $287 \cdot 7 \pm 14 \cdot 6$ & $46 \cdot 7 \pm 2 \cdot 6$ & $0.16 \pm 0.01$ \\
\hline Met-deficient for $6 \mathrm{~d}$ & $219 \cdot 6 \pm 10 \cdot 6$ & $29 \cdot 2 \pm 1 \cdot 8$ & $0.13 \pm 0.01$ \\
\hline $\begin{array}{l}\text { Level of significance, } P \text { : } \\
\text { Complete } v \text {. met-deficient plus } \\
2 \text { d complete }\end{array}$ & NS & $N s$ & NS \\
\hline $\begin{array}{l}\text { Complete } v \text {, met-deficient plus } \\
\text { I d complete }\end{array}$ & NS & NS & NS \\
\hline Complete $v$. met-deficient & $<0.001$ & $<0.001$ & $<0.01$ \\
\hline $\begin{array}{l}\text { Met-deficient plus } 2 \mathrm{~d} \text { complete } v \\
\text { met-deficient plus I d complete }\end{array}$ & NS & NS & NS \\
\hline $\begin{array}{l}\text { Met-deficient plus } 2 \mathrm{~d} \text { complete } v \text {. } \\
\text { met-deficient }\end{array}$ & $<0.05$ & $<0.001$ & $=0.05$ \\
\hline $\begin{array}{l}\text { Met-deficient plus I d complete } v \text {. } \\
\text { met-deficient }\end{array}$ & $<0.001$ & $<0.001$ & $=0.05$ \\
\hline \multicolumn{4}{|c|}{ For further details, see Table 2. NS, not significant. } \\
\hline
\end{tabular}

In skeletal muscle, recovery of ribosomal activity was complete after $\mathrm{I} d$ of refeeding (Tables 5 and 6). In addition, after methionine deficiency the activity per wet weight of muscle was restored within I d; after lysine deficiency the activity per wet weight was not restored after $2 \mathrm{~d}$ of refeeding. Recovery of liver activity from lysine deficiency was less pronounced (Table 6). Neither ribosomal activity nor activity per wet weight of tissuc was completely restored after $2 \mathrm{~d}$ of refeeding. After the Ist day of refeeding no changes in ribosomal activity had taken place, but activity per wet weight of liver was significantly increased at this time.

Although not significant, an increase in RNA content per g wet weight of skeletal muscle was observed after refeeding with methionine for $\mathrm{I} d$ or with lysine for $2 \mathrm{~d}$. In liver the changes during recovery from lysine deficiency were less pronounced.

\section{Expt 3. Effect of dietary energy level on protein synthesis in skeletal muscle and liver}

After $6 \mathrm{~d}$ there were significant differences in the daily increase in body-weight and in total liver weight (Table 7). However, the incorporation of amino acids into protein per ribosomal RNA was unaffected in both skeletal muscle and liver. The activity per wet weight of skeletal muscle started to decrease at an energy intake of I4 $\mathrm{I} \mathrm{KJ}$ and was significantly decreased when $106 \mathrm{KJ}$ were given. A similar sequence of events was observed with the RNA content.

In liver a significant decrease in ribosomal activity as well as in RNA content was obtained when the energy intake was as low as ro6 KJ. It may be mentioned that 
Table 6. Expt 2. Effect on protein synthesis in skeletal muscle and liver of rats of refeeding with lysine after $6 d$ on a lysine-deficient diet

(Mean values with their standard errors for four rats/group)

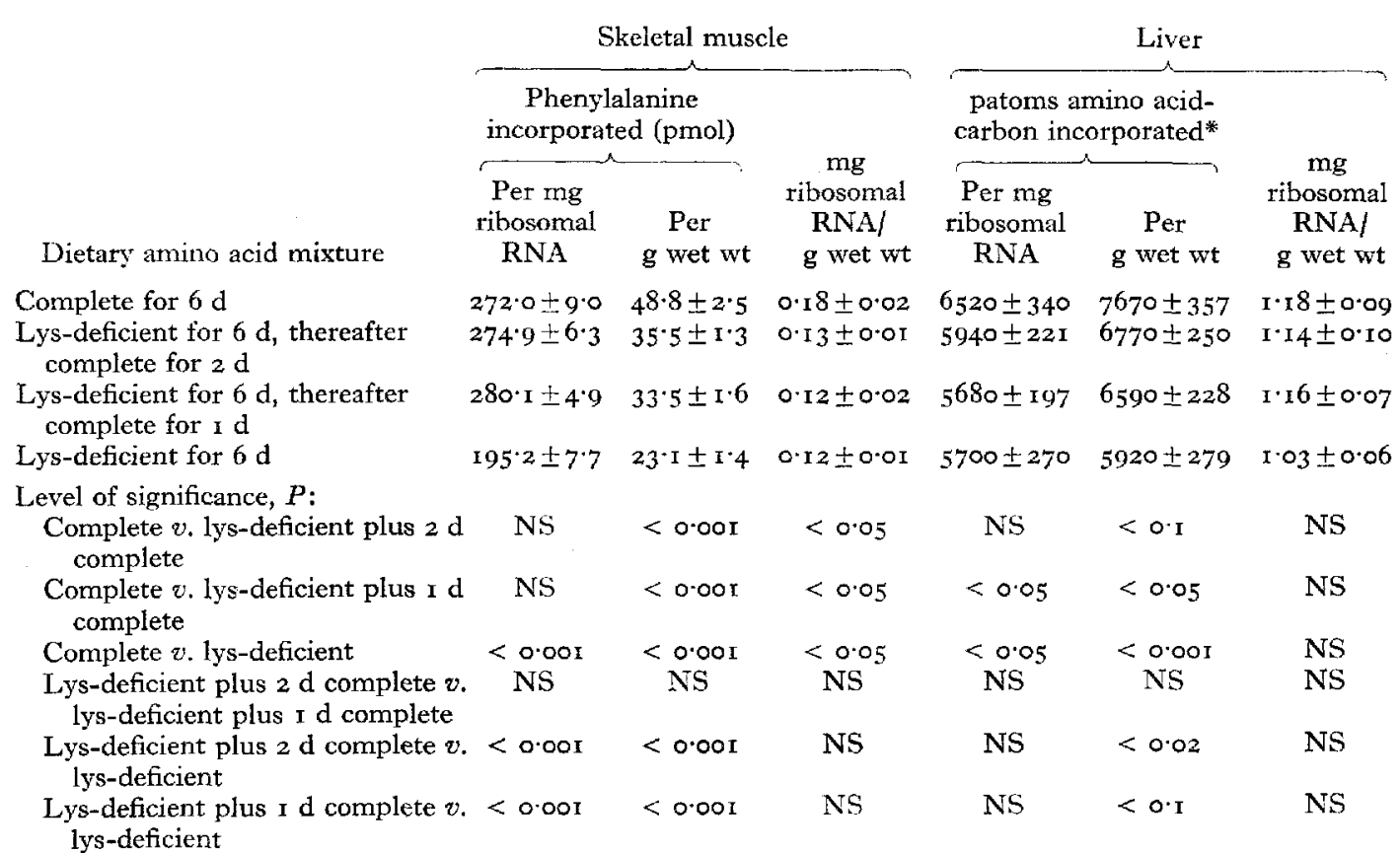

* Liver ribosomes were incubated with ${ }^{14} \mathrm{C}$-labelled algal protein hydrolysate. On the assumption that amino acids are incorporated in the same proportion as they are present in the hydrolysate, 1 patom of incorporated carbon corresponds to $0.207 \mathrm{pmol}$ amino acids.

NS, not significant.

For further details, see Table 2.

in liver the highest RNA concentration did not correspond to the highest energy intake but was at the level of $176 \mathrm{KJ}$.

Under the dietary conditions described in Expts I and 2, the amount of food eaten by the experimental rats was between 8 and $15 \mathrm{~g} / \mathrm{d}$. This corresponded to an energy intake of $14 \mathrm{I}-26_{3} \mathrm{KJ} / \mathrm{d}$. Thus, the differences obtained in protein synthesis in Expt $I$ and 2 were an effect of the dietary composition, and not of the level of energy intake.

\section{DISCUSSION}

The degree of utilization of amino acid mixtures for body metabolism depends on the ratio of essential to non-essential amino acids. An optimum ratio would seem to be that found in proteins of high biological value (Wretlind, 1972). The amino acid composition of whole egg was used in the present study. It is possible that optimal performance is not readily obtained by giving amino acids orally. As compared with a high-quality protein, oral feeding with amino acids resulted in a reduced amount of ribosomes in skeletal muscle and thus in a reduced capacity for protein synthesis per $\mathrm{g}$ wet weight of tissue. Ribosomal activity was unaffected. In liver, 
Table 7. Expt 3. Effect of the energy level of a diet containing $200 \mathrm{~g}$ casein $/ \mathrm{kg}$ on protein synthesis in skeletal muscle and liver of rats after $6 d$ of dietary treatment

(Mean values with their standard errors for four rats/group)

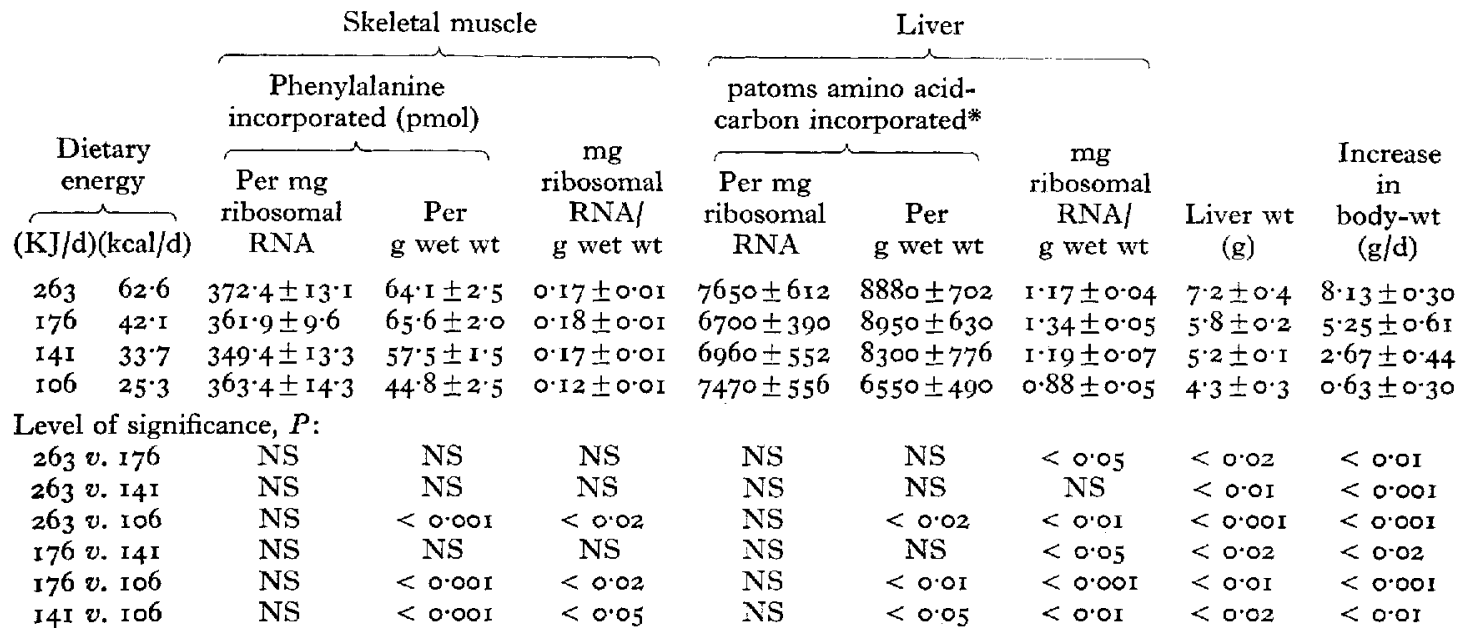

Casein was supplemented with $\mathbf{3} \mathrm{g}$ methionine/kg.

$\mathrm{NS}$, not significant.

* Liver ribosomes were incubated with ${ }^{14} \mathrm{C}$-labelled algal protein hydrolysate. For further details see Tables 2 and 6 .

activity per $\mathrm{g}$ wet weight was lower with the complete amino acid mixture when compared with casein plus methionine, whereas activity per mg ribosomal RNA was similar to that of casein plus methionine in one test series and lower in the other. However, taken together, casein plus methionine seems to be superior to the amino acid mixture as a dietary nitrogen source. It has been reported (ZimmermannNielson \& Schønheyder, 1962) that protein hydrolysates are absorbed more rapidly than intact protein which has to be digested before absorption. It is possible that the observed differences in the rate of protein synthesis per $\mathrm{g}$ wet weight of tissue are the result of either a less efficient or a too-fast absorption of free amino acids which are available in too high a concentration at a given time.

Between experiments using the same diet there is a certain variability in the level of protein synthesis. Although the conditions in the animal house are kept as constant as possible, environmental and seasonal factors cannot be excluded in having an influence on the animals. (For discussion see Omstedt $\&$ von der Decken, 1972.) In order to control these factors a high-quality nitrogen source is included as a reference in each test series.

The diets used in the deficiency studies were devoid of an essential amino acid, the remaining amino acids being present in adequate amounts. According to the definition introduced by Harper, Benevenga \& Wohlhueter (1970), the diets used were deficient but not imbalanced. Investigations of imbalances would therefore involve surpluses of indispensable amino acids other than the most limiting one.

A comparison between wheat gluten, in which lysine is the most limiting amino acid, and an amino acid mixture devoid of lysine indicates the pronounced sensitivity 
of skeletal muscle ribosomes to the complete absence of lysine in the diet. Conversely, there was no difference in liver ribosomal activity after feeding the rats with wheat gluten or with lysine-deficient diets. The differences between these tissues were apparent also during methionine and tryptophan deficiency.

Homeostatic mechanisms for the regulation of body fluid amino acids are artificially excluded by force-feeding rats with an amino acid-deficient diet. The results obtained by Sidransky, Wagle \& Verney (1969) on rat liver indicate an increase in protein synthesis after force-feeding on a threonine-deficient diet. The discrepancy between these results and those presented here clearly indicates the importance of well-defined conditions for food intake and the problems concerned with studies on metabolic responses by nutrients.

The results obtained in this investigation indicate that the maximal daily energy intake has to be decreased by more than $50 \%$ before an effect on protein synthesis in skeletal muscle and liver is observed. The diet contained a high-quality protein at a concentration of $200 \mathrm{~g} / \mathrm{kg}$ and was given at various levels of energy intake.

Under unfavourable nutrition conditions, protein metabolism is profoundly changed. In vivo this is determined by measuring the turnover rate, which will reflect changes in catabolism of proteins (Waterlow \& Stephen, I968). The nature of other regulatory mechanisms affecting protein metabolism has been discussed by Waterlow (1969). Furthermore, from in vitro studies it is known that the rate of protein synthesis is altered by partial protein deficiency. There are several possible reasons for the changes in ribosomal activities observed. The capability for elongation of existing polypeptide chains is decreased although no change in the monoribosome: polyribosome ratio was detected (von der Decken \& Omstedt, 1970). A similar state of so-called arrested polyribosomes has been described in cell cultures of chick embryos grown in serum-free medium (Soeiro \& Amos, I966). An effect on initiation might be partly responsible for changes in ribosomal activity. The capacity for this reaction, however, is fairly limited in cell-free systems (Morgan, von der Decken \& Hultin, $196 \mathrm{r}$ ).

Under the dietary conditions described here the ribosomal concentration per $g$ wet weight decreases in skeletal muscle, and to some extent also in liver. Hence, together with a decreased ribosomal activity, the dietary effect per $g$ wet weight of tissue becomes more pronounced.

It has been shown previously (von der Decken, 1967, 1968, 1969; von der Decken \& Omstedt, 1970; Omstedt \& von der Decken, 1972) that protein synthesis in skeletal muscle and in liver is increased after feeding with proteins during I d subsequent to 3 or $5 \mathrm{~d}$ of protein starvation. Refeeding with an adequate-protein diet after $\mathrm{I} 2$ weeks of protein restriction caused a partial recovery from hepatic lesions within $48 \mathrm{~h}$ (Enwonwu \& Sreebny, 1971). The present results are in agreement with the findings that recovery from amino acid deficiency is possible. Ribosomal activity in skeletal muscle is restored within $\mathrm{x} d$; however, depending on the amino acid studied, the amount of ribosomes and thus the activity per wet weight may require more than $2 \mathrm{~d}$ for recovery. Liver activity was restored less rapidly, but a significant increase in activity occurred within $2 \mathrm{~d}$ of refeeding. These results 
emphasize the metabolic differences between the tissues that are affected by the nutritional conditions applied.

The work was supported by research grants from The Swedish Natural Science Research Council (project no. 2520-09) and The Swedish Cancer Society (project no. $\left.{ }_{159}-\mathrm{B}_{72}-05 \mathrm{X}\right)$. The skilled technical assistance of Mrs Ch. Olgar is gratefully acknowledged. One of us (P.T.O.) was in receipt of a fellowship from Statens Konsumentverk, Sweden.

\section{REFERENCES}

Enwonwu, C. O. \& Sreebny, L. M. (1971). F. Nutr. ror, 501.

FAO (1970). FAO nutr. Stud. no. 24.

Harper, A. E., Benevenga, N. J. \& Wohlhueter, R. M. (1970). Physiol. Rev. 50, 428.

Lowry, O. H., Rosebrough, N. J., Farr, A. L. \& Randall, R. J. (1951). J. biol. Chem. 193, 265.

Mans, R. J. \& Novelli, G. D. (196I). Archs Biochem. Biophys. 94, 48.

Morgan, W. S., von der Decken, A. \& Hultin, T. (1961). Exp. Cell Res. 20, 655.

Ogur, M. \& Rosen, G. (1950). Archs Biochem. Biophys. 25, 262.

Omstedt, P. T. \& von der Decken, A. (1972). Br. F. Nutr. 27, 467.

Omstedt, P. T., von der Decken, A., Hedenskog, G. \& Mogren, H. (1973). F. Sci. Fd Agric. $24,1103$.

Peters, R. F., Richardson, M. C., Small, M. \& White, A. M. (1970). Biochem. F. 116, 349.

Sidransky, H., Wagle, D. S. \& Verney, E. (1969). Lab. Invest. 20, 364.

Soeiro, R. \& Amos, H. (1966). Science, N.Y. 154, 662.

von der Decken, A. (1967). F. Cell Biol. 33, 657 .

von der Decken, A. (1968). Eur. Y. Biochem. 4, 87.

von der Decken, A. (1969). F. Cell Biol. 43, 138.

von der Decken, A. \& Omstedt, P. T. (1970). F. Nutr. 1oo, 623 .

von der Decken, A. \& Omstedt, P. T. (1972). Э. Nutr. I02, I 555.

Waterlow, J. C. (1969). In Mammalian Protein Metabolism Vol. 3, p. 326 [H. N. Munro, editor]. New York and London: Academic Press.

Waterlow, J. C. \& Stephen, J. M. L. (1968). Clin. Sci. 35, 287.

Wettstein, F. O., Staehelin, T. \& Noll, H. (1963). Nature, Lond. 197, 430.

Wretlind, A. (1972). Nutr. Metab. r4, Suppl. p. I.

Zimmermann-Nielsen, C. \& Schønheyder, F. (1962). Biochim. biophys. Acta 63, 201. 